GRASAS Y ACEITES 70 (4)

October-December 2019, e335

ISSN-L: 0017-3495

https://doi.org/10.3989/gya.1179182

\title{
Valorization of a high-acidity residual oil generated in the waste cooking oils recycling industries
}

\author{
P. Álvarez-Mateos ${ }^{\mathrm{a}}$, J.F. García-Martín ${ }^{\mathrm{a}, \bowtie}$, F.J. Guerrero-Vacas ${ }^{\mathrm{a}}$, \\ C. Naranjo-Calderón ${ }^{\mathrm{a}}$, C.C. Barrios-Sánchez ${ }^{\mathrm{b}}$ and M.C. Pérez-Camino ${ }^{\mathrm{c}}$ \\ ${ }^{a}$ Departamento de Ingeniería Química, Facultad de Química, Universidad de Sevilla, \\ C/ Profesor García González, 1, 41012 Seville, Spain. \\ ${ }^{\mathrm{b}}$ Environmental Department, Research Centre for Energy, Environment and Technology (CIEMAT), \\ Avda. Complutense, 40, 28040 Madrid, Spain. \\ ${ }^{c}$ Instituto de la Grasa, C.S.I.C., Campus Universidad Pablo de Olavide, 41013 Seville, Spain. \\ Corresponding author: jfgarmar@us.es
}

Submitted: 21 November 2018; Accepted: 07 February 2019. Published online: 23 July 2019

\begin{abstract}
SUMMARY: A sludge fraction is obtained from the industries which recycle cooking oil and this sludge contains a large amount of oil with an extremely high acidity $(>60 \%)$. In this work, we propose a scheme for methyl ester production from this residual oil consisting of the esterification of the free fatty acids followed by the transesterification of the remaining triglycerides. Esterifications were carried out with different methanol:oil molar ratios, and various catalysts in different weight ratios. The results revealed that homogeneous catalysts produced higher yields than heterogeneous ones in the esterification reaction. With the aim of improving the process, a previous triglyceride hydrolysis was assayed using lipases from Candida rugosa. Finally, the 3-stage process was performed under the most favorable conditions for each stage obtaining $84 \%$ wt. fatty acid methyl esters, which shows the potential of this residual oil as a source of biodiesel.
\end{abstract}

KEYWORDS: Acidity; Biodiesel; Esterification; Methyl esters; Waste-cooking oil

RESUMEN: Valorización de un aceite residual de alta acidez generado en las industrias de reciclaje de aceites de desecho de cocinas. En las industrias de recogida y reciclado de aceites de fritura usados se obtiene una fracción de lodos que contiene un gran porcentaje de aceite con un extremadamente alto índice de acidez ( $>60 \%)$. En este trabajo proponemos un esquema de producción de ésteres metílicos basado en la esterificación de los ácidos grasos libres seguida de la transesterificación de los triglicéridos remanentes. Las esterificaciones se llevaron a cabo usando diferentes relaciones molares metanol:aceite y diversos catalizadores en diferentes concentraciones en peso. Los resultados ilustraron que los catalizadores homogéneos alcanzaron mayores rendimientos en la esterificación que los catalizadores heterogéneos. Para mejorar el proceso, se probó una hidrólisis previa con lipasas de Candida rugosa. Finalmente, se llevó a cabo el proceso con las 3 etapas, en las condiciones más favorables de cada una de ellas, obteniendo un $84 \%$ en peso de ésteres metílicos, lo que muestra el potencial de este aceite residual como fuente de biodiésel.

PALABRAS CLAVE: Aceite de fritura usado; Acidez; Biodiésel; Ésteres metílicos; Esterificación

ORCID ID: Álvarez-Mateos P https://orcid.org/0000-0001-9225-219X, García-Martín JF https://orcid.org/0000-00024582-560X, Guerrero-Vacas FJ https://orcid.org/0000-0001-9741-0775, Naranjo-Calderón C https://orcid.org/00000002-9671-802X, Barrios-Sánchez CC https://orcid.org/0000-0002-6462-6219, Pérez-Camino MC https://orcid. org/0000-0001-7652-9582

Citation/Cómo citar este artículo: Álvarez-Mateos P, García-Martín JF, Guerrero-Vacas FJ, Naranjo-Calderón C, Barrios-Sánchez CC, Pérez-Camino MC. 2019. Valorization of a high-acidity residual oil generated in the waste cooking oils recycling industries. Grasas Aceites 70 (4), e335. https://doi.org/10.3989/gya.1179182

Copyright: (C2019 CSIC. This is an open-access article distributed under the terms of the Creative Commons Attribution 4.0 International (CC BY 4.0) License. 


\section{INTRODUCTION}

The per-capita consumption of oil in Spain stood at 12.6 liters per person per year in 2016, which means a consumption of more than 580 million litres (Ministerio de Agricultura y Pesca Alimentacion y Medio Ambiente, 2017). A large percentage of consumed oil is used for the frying process which consists of placing food in an oil bath at temperatures between 160 and $200^{\circ} \mathrm{C}$ (Cvengroš and Cvengrošová, 2004) during a certain period of time and in the presence of air. Consequently, the oil suffers physical and chemical changes. The most common physical changes are increase in viscosity due to remains of food present in the oil and the formation of polymers (Nawar, 1984; Mittelbach and Enzelsberger, 1999), perceptible sensory changes (smell, color and taste) due to the presence of hydrocarbons, ketones and acids (Nawar, 1984; Cvengroš and Cvengrošová, 2004), decrease in surface tension because the increase of thermal agitation decreases the cohesion forces (Cvengroš and Cvengrošová, 2004), and decrease in the iodine value (degree of unsaturation of the oil) due to the breakdown of double bonds by oxidation and polymerization (Sánchez-Gimeno et al., 2008). The chemical changes produced in frying oils are due to the high temperatures (thermolytic reactions), the presence of oxygen (oxidation reactions) and the presence of water (hydrolysis reaction).

The discharge of waste cooking oils (WCO) into sewage causes numerous negative effects, namely the production of sludge, eutrophication and proliferation of bacteria and pathogenic microorganisms, death of living beings, blockages in the collectors, and the plugging and corrosion of plumbing (González and González, 2015). Furthermore, the polluting load of one litre of WCO is 5,000 times greater than the pollutant load of 1 liter of wastewater, and 1 liter of WCO can cause the contamination of 40,000 litres of water (González and González, 2015). In order to avoid these issues, a proper management of these WCO is required. In addition, WCO can be a source of income for waste management companies, since this raw material is cheaper than vegetable oil and first-hand animal fats for biodiesel production (García-Martín et al., 2018).

The WCO collection companies are responsible for the collection, transport, storage and recovery of used vegetable oil from the hotel, restaurant and catering (HORECA) sector or domestic origin. Their objective is to obtain oil with a low acidity index to sell it to companies that produce biodiesel and for this, it is necessary to submit the WCO to a previous treatment. The use of WCO to produce biodiesel also reduces disposal management costs. The waste cooking oil goes through different stages to obtain a clean oil with a low acidity index (Figure 1): First, the WCO passes through a sieve in which the largest solid particles (mainly from flour batter) are retained. Then, the rest of the oil and smaller solid particles are left to decant for $5 \mathrm{~h}$ at $41{ }^{\circ} \mathrm{C}$ in horizontal deposits, where three different phases are separated by density. In the upper part there is the oil (normally with low acidity, ready to be sold to biodiesel industries), followed by a water phase containing suspended solids, and a sludge fraction. Finally, some WCO collection companies, such as Grupo BIOSEL (Spain), make the sludge go through a centrifugation stage, obtaining three phases: a concentrate sludge, a high acidity index oil and wastewater. The residual oil obtained in the tricanter is an olein, since its composition is mainly triglycerides and free fatty acids (FFA) the percentage of these latter being more than 50\% (Pereda Marín et al., 2003). Because of its high acidity index, this residual oil cannot be used to obtain biodiesel by the usual procedure (transesterification in an alkaline medium) due to the formation of soaps. A previous esterification with methanol to obtain fatty acid methyl esters (FAME) using an acid catalyst according to Eq. (1) can overcome this problem:

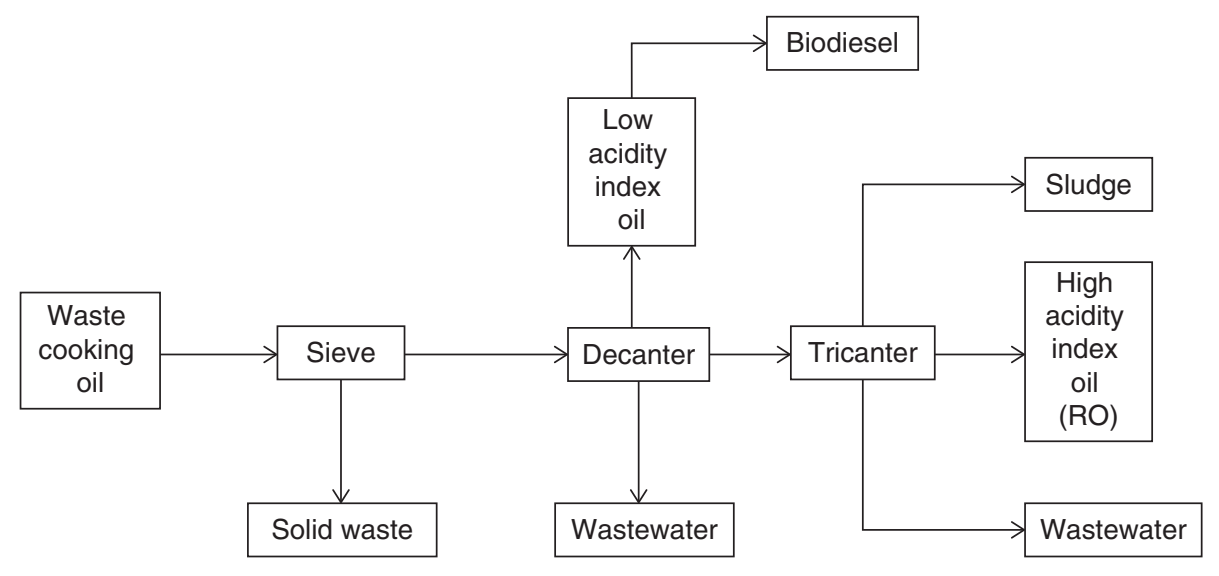

FIgURE 1. WCO treatment at Grupo BIOSEL facilities. 


$$
\begin{aligned}
& \mathrm{CH}_{3}-\mathrm{OH}+\mathrm{R}-\mathrm{COOR} \leftrightarrow \\
& \mathrm{R}-\mathrm{COO}-\mathrm{CH}_{3}+\mathrm{H}_{2} \mathrm{O}
\end{aligned}
$$

This reaction is reversible and water is produced so an excess of water displaces the equilibrium towards the formation of reactants thus reducing the yield of the reaction. Once the FFA have been transformed into FAME, triglycerides are subjected to a transesterification reaction with methanol using an alkaline catalyst (Leung and Guo, 2006; Chai et al., 2014).

Another alternative is to esterify first the FFA with glycerol (glycerolysis) at high temperature and under vacuum conditions using the Lewis acid catalysts to transform them into triglycerides (Vitiello et al., 2017) according to Eq. (2), and transesterify the triglycerides with methanol using an alkaline catalyst.

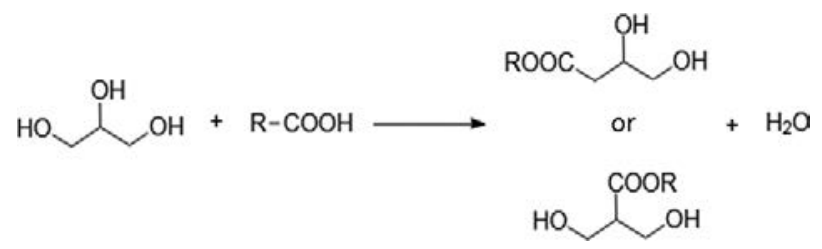

Finally, one last procedure consists of hydrolyzing the triglycerides with an enzyme (lipase) in aqueous medium thus transforming the triglycerides into FFA, then esterifying the FFA with methanol and an acid catalyst into FAME (Botton et al., 2018).

The main objective of this work was to valorize a residual oil that currently does not have economic application through its conversion into FAME (biodiesel). Since the residual oil had a high acidity index, we tried to optimize the esterification of the free fatty acids prior to performing the triglyceride transesterification. To increase FAME yield, we assayed the previous hydrolysis of triglycerides by lipases, thus increasing the residual oil acidity index. Finally, we assayed a 3-stage scheme (hydrolysis, esterification and transesterification) under the most suitable conditions of each one.

\section{MATERIALS AND METHODS}

\subsection{Raw material}

Grupo BIOSEL supplied the residual oil (RO) used in this research.

\subsection{Fatty acid methyl ester production}

FAME from residual oil were obtained by esterification (with or without previous triglyceride hydrolysis) of free fatty acid and by transesterification of the remaining triglycerides (TG).
Hydrolysis. In order to hydrolyze and transform the oil triglycerides into free fatty acids, lipases from Candida rugosa were employed. The hydrolyses were conducted in a $500-\mathrm{cm}^{3}$ conical flask with vigorous shaking in a standard orbital shaker. The procedure is summarised as follow: $100 \mathrm{~cm}^{3}$ of oil sample were heated at $30{ }^{\circ} \mathrm{C}$ for $30 \mathrm{~min}$. After the addition of the desired amount of lipase dissolved in $10 \mathrm{~cm}^{3}$ of deionized water (milli-Q), the mixture was vigorously shaken. The conditions assayed included an enzyme concentration between 0.6 and $1.2 \mathrm{~g} \mathrm{dm}^{-3}$ acting at $\mathrm{pH} 7,30^{\circ} \mathrm{C}$ temperature, $1 \mathrm{~atm}$ pressure, water-to-oil molar ratios from 1:2 to $4: 1$ (v/v) (Table 2) and $24 \mathrm{~h}$ reaction time. These conditions were chosen because they are in the range of more suitable conditions for TG hydrolysis pointed out by other authors (Chowdhury et al., 2016). Subsequently, the samples were centrifuged and the oil phase was separated from the aqueous phase and the acidity index of the oil phase was determined. The yield of the hydrolysis reaction $\left(\eta_{H}\right)$ was defined as follow:

$$
\eta_{\mathrm{H}}(\%)=\frac{\left(\mathrm{AI}_{f}-\mathrm{AI}_{i}\right)}{100-\mathrm{AI}_{i}} \times 100
$$

Where $\mathrm{AI}_{i}$ is the initial acidity index $(60.5 \%)$ and $\mathrm{AI}_{f}$ stands for the acidity index at the end of the hydrolysis process.

Esterification. The esterification reaction of FFA contained in $100 \mathrm{~cm}^{3}$ sample was carried out in a $500-\mathrm{cm}^{3}$ stirred tank reactor, provided with a Heidolph RZR 2052 stirrer and a coolant to avoid losses in methanol. The working conditions were $60{ }^{\circ} \mathrm{C}$ temperature, $700 \mathrm{rpm}$ stirring and $2 \mathrm{~h}$ reaction time. Different types of homogeneous ( $\mathrm{HCl}$ and $\mathrm{H}_{2} \mathrm{SO}_{4}$ ) and heterogeneous (commercial Amberlyst-15 supplied by The Dow Company, Midland, Michigan, United States, heavy-metalcontaminated pyrolyzed roots from Jatropha curcas L., and pyrolyzed roots from Jatropha curcas $\mathrm{L}$. treated with $\mathrm{H}_{3} \mathrm{PO}_{4}, \mathrm{KOH}$ or $\mathrm{CO}_{2}$ ) catalysts were assayed. Different weight percentages of catalyst $(3,5,8,10$ and $15 \%$ wt.) and various methanol-to-oil molar ratios $(2: 1,8: 1,10: 1,15: 1$ and 20:1) were also assayed. After esterification, the acid catalyst used in the esterification was neutralized with a $\mathrm{NaOH}$ in ethanol solution. The esterification yield $\left(\eta_{\mathrm{E}}\right)$ was calculated as follow:

$$
\eta_{\mathrm{E}}(\%)=\frac{\left(\mathrm{AI}_{f}-\mathrm{AI}_{i}\right)}{\mathrm{AI}_{i}} \times 100
$$

where $\mathrm{AI}_{i}$ is the initial acidity index $(60.5 \%)$ and $\mathrm{AI}_{f}$ stands for the acidity index at the end of the esterification. 
Transesterification. For the transesterification of the resulting mixture from the esterification reaction, a $1-\mathrm{dm}^{3}$ stirred tank reactor was used. The initial working conditions were: $60{ }^{\circ} \mathrm{C}$ temperature, $700 \mathrm{rpm}$ stirring, $1 \mathrm{~h}$ reaction time, 8:1 methanolto-oil molar ratio and $1 \%$ (wt.) $\mathrm{NaOH}$ in relation to the oil as catalyst. These conditions were chosen based on our previous research (Pereda Marín et al., 2003; García-Martín et al., 2018, 2019a). After the transesterification reaction, a decanting step was carried out to separate impurities from FAME. For this purpose, the mixture was transferred to a separating funnel and left to decant until a complete separation into two phases was observed. In the upper phase, the biodiesel was found together with methanol, water and soaps, while the lower phase contained a mixture of glycerine, methanol, soaps, salts and water. Once the two phases were separated, the methanol was removed from the biodiesel phase using a Rotavapor- $\mathrm{R}$ and a vacuum pump Diaphragm Vacuum Pump GM100 at room temperature. Finally, a filtration step was carried out using a mesh filter containing oak chips with alumina, as described elsewhere (García-Martín et al., 2018, 2019a), which allows the passage of the methyl esters while retaining the rest of the soaps, glycerol, salts and water.

\subsection{Biocatalysts production}

Biocatalysts were the resulting biochars from the pyrolysis of roots from Jatropha curcas L. plants grown in non-contaminated soils and treated with $\mathrm{H}_{3} \mathrm{PO}_{4}$ (Biocatalyst 1), $\mathrm{KOH}$ (Biocatalyst 2) or $\mathrm{CO}_{2}$ (Biocatalyst 3), and from the pyrolysis of roots from J. curcas L. Plants, used for the phytoremediation of contaminated soils with different heavy metal concentrations (Biocatalyst 4 and Biocatalyst 5).

Biocatalysts from non-contaminated J. curcas L. roots. Biocatalysts 1 and 2 were chemically activated by means of a treatment with an acid or a base, respectively, prior to the carbonization process. In this process, the root samples were impregnated with $\mathrm{H}_{3} \mathrm{PO}_{4}$ (Biocatalyst 1) or $\mathrm{KOH}$ (Biocatalyst 2) in a $1: 2$ mass ratio and dried in an oven at $60^{\circ} \mathrm{C}$ for $22 \mathrm{~h}$. In order to eliminate the excess of acid or base, the samples were washed with water until reaching a $\mathrm{pH}$ value close to 7 . The solids obtained after washing were again dried in an oven at $60{ }^{\circ} \mathrm{C}$ for $22 \mathrm{~h}$ (Bastidas et al., 2010). Subsequently, the pyrolysis of both samples was carried out at $600{ }^{\circ} \mathrm{C}$ for $2 \mathrm{~h}$ with a heating rate of $10^{\circ} \mathrm{C} \cdot \mathrm{min}^{-1}$ and an argon flow rate of $150 \mathrm{~cm}^{3} \cdot \mathrm{min}^{-1}$.

Biocatalyst 3 was obtained by direct physical activation of the plant roots, combining the process of thermal carbonization and the activation by oxidation using $\mathrm{CO}_{2}$ as oxidizing agent in the same step. This thermal treatment of reduction was accomplished by the treatment of the sample with $\mathrm{CO}_{2}$ at $600{ }^{\circ} \mathrm{C}$. The oxidizing agent reacts with the carbon atoms generating a porous structure. The oxidizing atmosphere brings about changes in the chemical and physical properties of coal. Plasticity is physically eliminated, the formation of a porous texture is favored, and the oxygenated groups are chemically increased with a decrease in the aliphatic groups that are the most vulnerable structures in the oxidation (Uribe et al., 2013). Subsequently, pyrolysis was carried out for $2 \mathrm{~h}$ at the same temperature $\left(600{ }^{\circ} \mathrm{C}\right)$ under argon atmosphere at a flow rate of $150 \mathrm{~cm}^{3} \cdot \mathrm{min}^{-1}$ with the aim of improving the adsorbent capacity of the biochars.

Biocatalysts from heavy-metal-contaminated J. curcas L. roots. The dried and sieved roots of J. curcas L. plants that were previously used for the phyto-remediation of 2 heavy-metal contaminated soils (ÁlvarezMateos et al., 2019) were subjected to pyrolysis to obtain 2 biocatalysts. Biocatalyst 4 was obtained from roots containing 31.8, 39.2, 1118.3, 13.7, 16.4, 44.7 and $22.4 \mathrm{mg} \cdot \mathrm{kg}^{-1} \mathrm{Cr}, \mathrm{Mn}, \mathrm{Fe}, \mathrm{Ni}, \mathrm{Cu}, \mathrm{Zn}$ and $\mathrm{Pb}$, respectively, while the roots used for the synthesis of Biocatalyst 5 contained 45.9, 69.7, 1841.6, 21.9, 22.4, 124.1 and $57.1 \mathrm{mg} \cdot \mathrm{kg}^{-1} \mathrm{Cr}, \mathrm{Mn}, \mathrm{Fe}, \mathrm{Ni}, \mathrm{Cu}, \mathrm{Zn}$ and $\mathrm{Pb}$, respectively.

Pyrolysis of $0.5 \mathrm{~g}$ of each root took place inside a $25 \times 300$ quartz tube placed in a Carbolite Tube Furnace MTF 12/38/250 equipped with a Eurotherm 2416CG temperature controller. The outlet of the quartz tube was connected to two bubblers submerged in ice to condense the flue gases (bio-oils), with an extractor hood to eliminate the uncondensed gases. The $\mathrm{N}_{2}$ flow was set to $6 \mathrm{dm}^{3} \cdot \mathrm{h}^{-1}$, and the heating rate to $30^{\circ} \mathrm{C} \cdot \mathrm{min}^{-1}$ until reaching $550^{\circ} \mathrm{C}$, which was maintained for $2 \mathrm{~h}$. The resulting biochars had graphite-like structure based on Raman spectra analysis (Álvarez-Mateos et al., 2019) and have shown a great performance in the catalysis of similar reactions such as glycerol esterification with acetic acid or acetic anhydride to obtain oxygenated fuel additives (García-Martín et al., 2019b).

\subsection{Analytical methods}

Free fatty acids were quantified in the starting residual oil and after each reaction using the acidity index (AI) parameter (UNE-EN 140140). The AI was determined by titration with an ethanolic $0.1 \mathrm{~N} \mathrm{KOH}$ solution and expressed as oleic acid percentage (García Martín et al., 2019c). All measurements were performed in triplicate.

The composition of the starting $\mathrm{RO}$ and the samples resulting from the hydrolysis, esterification and transesterification reactions, in terms of glyceride compounds, was analyzed by high performance size exclusion chromatography (HPSEC). This technique consists of the separation of the compounds 
according to their molecular size. The elution order was as follows: Polymers of triglycerides (trimers and dimers), triglycerides (TG), diglycerides (DG), monoglycerides (MG) and finally FFA or FAME. For their quantification, a liquid chromatograph Hewlett Packard 1050 working with an isocratic flow rate of $0.7 \mathrm{~cm}^{3} \cdot \mathrm{min}^{-1}$ of tetrahydrofuran (THF) was used. The equipment was provided with a manual rheodyne injector with a $20 \mu \mathrm{L}$ loop, a column Agilent PL-gel $3 \mu \mathrm{m}$ (size of pore $100 \AA$ ) and it was connected to a refractive index detector Merck $\mathrm{L}-7490$. The sample concentration was $50 \mathrm{mg} \cdot \mathrm{cm}^{-3}$ THF. The data was processed using the 32 Karat program (Beckman Coulter, Inc.). The total time of the chromatographic analysis was $15 \mathrm{~min}$.

The FAME content in samples was obtained following UNE-EN 14103:2011 and UNE-EN ISO 12966-1:2015 standards. Briefly, $50 \mathrm{mg}$ of WCO were dissolved in $2 \mathrm{~cm}^{3}$ heptane and then transesterified using a $0.3 \mathrm{~cm}^{3} 2 \mathrm{~N}$ methanolic $\mathrm{KOH}$ solution. After decanting, the supernatant was collected and FAME percentages were analyzed in an HP 5890 series II gas chromatograph equipped with a SP2380 capillary column $(60 \mathrm{~m} \times 0.25 \times 0.25 \mu \mathrm{m})$. The initial column temperature was $185^{\circ} \mathrm{C}$ and the ramp rate was $3{ }^{\circ} \mathrm{C} \mathrm{min}{ }^{-1}$ until reaching $220^{\circ} \mathrm{C}$. The injection was operated in splitless mode, the injector and detector temperatures were $225^{\circ} \mathrm{C}$ and $250{ }^{\circ} \mathrm{C}$, respectively. FAME were identified by mass spectrometry, comparing the spectra with those in a database for this type of compound (Wiley, NIST), and their concentration was calculated using methyl heptadecanoate as internal standard.

The texture characterization of the biochars was carried out using the BET method to determine the specific surface area and by the adsorption/desorption isotherms to study the pore structure. To do this, a Micrometrics Gemini V-2365//V.1.00 adsorption equipment as well as a Micrometrics TriStar II adsorption/desorption equipment, respectively, were used. The biochars were degassed at $250{ }^{\circ} \mathrm{C}$ for $24 \mathrm{~h}$ under $\mathrm{N}_{2}$ atmosphere.

\section{RESULTS AND DISCUSSION}

The starting residual oil was firstly characterized by HPSEC (Table 1) and GC. Polymers (trimers and dimers) were the first to elute in the HPSEC analysis, with retention times around 7.4 and $8.1 \mathrm{~min}$, respectively. Then triglycerides (TG) eluted at $8.7 \mathrm{~min}$ and diglycerides (DG) at $9.1 \mathrm{~min}$. Finally, FFA eluted at a retention time of $9.9 \mathrm{~min}$. Monoglycerides (MG) were not observed because they elute at a retention time very close to that of FFA so they overlap. The fatty acid composition obtained by GC was $0.17 \pm 0.04 \%$ myristic acid, $10.5 \pm 0.5 \%$ palmitic acid, $0.25 \pm 0.08 \%$ palmitoleic acid, $4.1 \pm 0.3 \%$ stearic acid, $39.6 \pm 1.1 \%$ oleic acid, $45.0 \pm 0.8 \%$ linoleic acid, $0.14 \pm 0.03 \%$ linolenic acid, and $0.16 \pm 0.07 \%$ palmitolenic acid.
TABLE 1. Composition of the starting residual oil (RO) and after hydrolysis with lipases (H1), subsequent esterification (HE1) and later transesterification (HE1T) under the most suitable conditions, and retention time (RT) of each compound

\begin{tabular}{|c|c|c|c|c|c|}
\hline \multirow[b]{2}{*}{ Compound } & \multirow{2}{*}{$\underset{(\mathrm{min})}{\mathrm{RT}}$} & \multicolumn{4}{|c|}{ Composition ( $\%$ wt.) } \\
\hline & & RO & H1 & HE1 & HE1T \\
\hline TG-trimers & 7.41 & 0.62 & 0.52 & n.d. & n.d. \\
\hline TG-dimers & 8.15 & 3.77 & n.d. & n.d. & n.d. \\
\hline $\mathrm{TG}$ & 8.72 & 19.44 & 12.55 & 12.20 & n.d. \\
\hline DG & 9.07 & 13.78 & 14.09 & 13.37 & 18.83 \\
\hline MG & n.d. & n.d. & n.d. & n.d. & n.d. \\
\hline $\mathrm{FFA}+\mathrm{FAME}$ & 9.93 & 62.39 & 72.84 & 74.43 & 81.17 \\
\hline
\end{tabular}

n.d. $=$ not detected

The percentage of free fatty acids obtained by HPSEC $(62.4 \%)$ was very similar to the acidity index obtained by the official method UNE-EN 140104 $(60.5 \%)$. This similarity of results demonstrates the suitability of the use of HPSEC as a method of monitoring the reactions.

The AI obtained for the RO $(60.5 \pm 0.2 \%)$ indicates that it is not suitable as a raw material for a transesterification reaction due to its high content of free fatty acids, since large quantities of soaps would be produced and therefore the reaction would occur only to a small extent (García Martín et al., 2019c). They cannot be used as oleins either due to their remarkable contents of triglycerides, diglycerides and monoglycerides (roughly $38 \%$ ). Therefore, the 3 proposed techniques (TG hydrolysis, FFA esterification and TG transesterification) were assayed to obtain methyl esters from this residual oil.

\subsection{Hydrolysis of triglycerides}

Hydrolysis was carried out to increase the number of free fatty acids in the residual oil by breaking down the triglyceride molecules, so a larger amount of FFA can be subsequently converted into FAME by esterification. If the TG hydrolysis were complete, the subsequent production of biodiesel would be performed via esterification of FFA without the need to resort to TG transesterification. For the hydrolysis of triglycerides to be carried out it is necessary to use a catalyst. In our case, lipases from the yeast Candida rugose were used. The experimental parameters assessed were the amount of lipase added $\left(0.06,0.08\right.$ and $0.12 \%$ wt.) and the $\mathrm{H}_{2} \mathrm{O}: \mathrm{RO}$ $(\mathrm{v} / \mathrm{v})$ ratio (from 4:1 to 1:2). In previous studies it was found that the maximum TG conversions were $93 \%$ for $1: 2(\mathrm{v} / \mathrm{v})$ ratio after $10 \mathrm{~h}$ reaction, $70 \%$ for $4: 1(\mathrm{v} / \mathrm{v})$ ratio after $24 \mathrm{~h}$ reaction, and $92 \%$ for $4.12: 1$ (v/v) ratio after $30 \mathrm{~h}$ reaction (Chowdhury et al., 2016). Based on these results, we assayed $\mathrm{H}_{2} \mathrm{O}: \mathrm{RO}$ ratios $(\mathrm{v} / \mathrm{v})$ within a similar range (from $4: 1$ to $1: 2$ ), 
fixing the reaction time to $24 \mathrm{~h}$. To assess the most suitable conditions for the hydrolysis reaction, the acidity index was chosen as the parameter to be followed.

Table 2 illustrates all the hydrolysis reactions carried out and the different reaction conditions. It shows the amount of lipase added as catalyst, the $\mathrm{H}_{2} \mathrm{O}: \mathrm{RO}$ ratio used, the final acidity of the oil and the yield $\left(\eta_{\mathrm{H}}\right)$ of the hydrolysis reaction.

The hydrolysis with 1:1 $\mathrm{H}_{2} \mathrm{O}: \mathrm{RO}(\mathrm{v} / \mathrm{v})$ ratio, for the same lipase concentration $(0.08 \%$ wt.) was the one that achieved the highest acidity index (85.4\%). Subsequently, lipase concentrations above and below $0.08 \%$ wt. were assayed $(0.12$ and $0.06 \%$ wt., respectively), obtaining average percentages of acidity of 72.2 and $70.7 \%$ wt., respectively. Therefore, the most suitable hydrolysis conditions were 0.08 percentage by weight of lipase with respect to the oil and 1:1 $\mathrm{H}_{2} \mathrm{O}: \mathrm{RO}(\mathrm{v} / \mathrm{v})$ ratio, under which an acidity index of $85.4 \%$ and reaction yield of $62.9 \%$, respectively, were achieved. The resulting sample contained $85.4 \%$ FFA and $14.7 \%$ TG, DG and MG.

\subsection{Esterification of free fatty acids}

Similarly to hydrolysis reactions, esterification reactions of FFA were monitored by the acidity index. The experiments were carried out with homogeneous and heterogeneous catalysts. The homogeneous catalysts used were sulphuric acid and hydrochloric acid since other acids such as nitric acid have been reported to achieve lower yields and

TABLE 2. Resulting acidity index (AI) and reaction yield

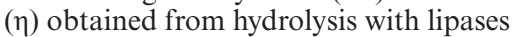

\begin{tabular}{lcccc}
\hline Run & (\% wt.) & $\mathbf{H}_{\mathbf{2}} \mathbf{O}: \mathbf{R O}$ & $\mathbf{A I}(\%)$ & $\boldsymbol{\eta}_{\mathbf{H}}(\mathbf{\%})$ \\
\hline H1 & 0.08 & $1: 1$ & $85.4 \pm 0.2$ & $62.9 \pm 0.1$ \\
H2 & 0.08 & $1: 2$ & $70.5 \pm 0.2$ & $25.4 \pm 0.1$ \\
H3 & 0.08 & $4: 1$ & $68.4 \pm 0.2$ & $20.2 \pm 0.1$ \\
H4 & 0.08 & $2: 1$ & $72.2 \pm 0.2$ & $29.7 \pm 0.1$ \\
H5 & 0.12 & $1: 1$ & $72.7 \pm 0.2$ & $29.6 \pm 0.3$ \\
H6 & 0.06 & $1: 1$ & $70.7 \pm 0.2$ & $25.7 \pm 0.3$ \\
\hline
\end{tabular}

are economically more expensive ( $\mathrm{Su}, 2013)$. The heterogeneous catalysts used were Amberlyst-15 and the 5 biocatalysts synthetized from $J$. curcas L. roots.

Homogeneous catalysts. Different concentrations of $\mathrm{H}_{2} \mathrm{SO}_{4}$ (wt.) were tested for the same 15:1 methanol:residual oil (MeOH:RO) molar ratio (Table 3). The best performance was achieved with $5 \%$ (wt.) $\mathrm{H}_{2} \mathrm{SO}_{4}$ (run E1). This result is in agreement with that reported by Marchetti and Errazu (2008), who studied the esterification of FFA with methanol at different concentrations of catalyst (1.0-5.2\% wt.), and concluded that 5\% (wt.) $\mathrm{H}_{2} \mathrm{SO}_{4}$ was the optimum catalyst dosage for this type of reaction (Marchetti and Errazu, 2008).

The difference in yield between sulphuric acid and hydrochloric acid was remarkable (Table 3). This is because the hydrochloric acid used was $37 \%$ wt. (63\% wt. water). As aforementioned, water is the product of esterification and causes equilibrium to shift towards the formation of reactants which inhibit the reaction (Botton et al., 2018).

The reaction products of the three esterifications with sulphuric acid (runs E1, E2 and E3) were analyzed by GC. The percentages of individual methyl esters were similar to those of the initial RO (Table 3). Therefore, and similarly to glyceride transesterification, fatty acid esterification does not alter the fatty acid profile in the resulting methyl esters mixture (García-Martín et al., 2019a). Furthermore, the percentages of FAME in the reaction products obtained by GC analyses $(66.0 \%$ for run E1, $63.4 \%$ forrun E2 and $56.7 \%$ for run E3) were in agreement with the esterification yield calculated through the AI parameter and the initial RO composition provided by HPSEC (Table 1 ).

When combining the most suitable conditions for TG hydrolysis with lipases (run H1, Table 2) and FFA esterification (run E1, Table 3), in spite of producing more methyl esters, the resulting yield of the two-process scheme (run HE1, Table 3) was lower than that of esterification alone (E1). This is probably due to the water generated in the previous hydrolysis because in order to hydrolyze the triglycerides, water was added in a ratio of $1: 1(\mathrm{v} / \mathrm{v})$

TABLE 3. Esterifications with homogenous catalysts

\begin{tabular}{|c|c|c|c|c|c|c|c|c|c|c|c|c|c|c|}
\hline \multirow[b]{2}{*}{ Run } & \multirow[b]{2}{*}{ Catalyst } & \multirow[b]{2}{*}{$\%$ wt. } & \multirow[b]{2}{*}{ MeOH:RO } & \multirow[b]{2}{*}{ AI $(\%)$} & \multirow[b]{2}{*}{$\eta_{\mathrm{E}}(\%)$} & \multicolumn{9}{|c|}{ Fatty acid methyl esters (\%) } \\
\hline & & & & & & 14:0 & 16:0 & 16:1 & 18:0 & 18:1 & $18: 2$ & $18: 3$ & $16: 3$ & Total FAMEs \\
\hline E1 & $\mathrm{H}_{2} \mathrm{SO}_{4}$ & 5 & $15: 1$ & $1.0 \pm 0.1$ & $98.3 \pm 0.8$ & 0.11 & 9.8 & 0.16 & 3.6 & 40.4 & 45.7 & 0.09 & 0.14 & 66.0 \\
\hline E2 & $\mathrm{H}_{2} \mathrm{SO}_{4}$ & 8 & $15: 1$ & $5.2 \pm 0.4$ & $91.5 \pm 0.3$ & 0.16 & 10.4 & 0.23 & 4.0 & 39.9 & 44.9 & 0.15 & 0.24 & 63.4 \\
\hline E3 & $\mathrm{H}_{2} \mathrm{SO}_{4}$ & 3 & $15: 1$ & $9.9 \pm 0.4$ & $83.6 \pm 0.3$ & 0.17 & 10.7 & 0.22 & 4.1 & 39.6 & 44.8 & 0.17 & 0.23 & 56.7 \\
\hline $\mathbf{E} 4$ & $\mathrm{HCl}$ & 4 & $10: 1$ & $31.0 \pm 0.5$ & $49.3 \pm 0.2$ & - & - & - & - & - & - & - & - & - \\
\hline HE1* & $\mathrm{H}_{2} \mathrm{SO}_{4}$ & 5 & $15: 1$ & $4.2 \pm 0.2$ & $95.0 \pm 0.7$ & 0.44 & 13.5 & 0.65 & 9.8 & 63.8 & 11.6 & 0.23 & 0.07 & 75.0 \\
\hline
\end{tabular}

14:0 = myristic acid; $16: 0$ = palmitic acid; $16: 1=$ palmitoleic acid; $18: 0=$ stearic acid; $18: 1=$ oleic acid; $18: 2=$ linoleic acid; $18: 3=$ linolenic acid; $16: 3=$ palmitolenic acid. $*$ with previous hydrolysis 
with respect to RO, which was not removed from the reaction medium to minimize operational costs, thus reducing the yield of the subsequent esterification by $3 \%$. In a study conducted on the influence of water on the esterification of fatty acids, it was observed that when the concentration of water was $5 \% \mathrm{wt}$., the conversion in the esterification reaction decreased by $30 \%$ (Botton et al., 2018). On the contrary, when the percentage of water in the reaction medium was greater, about $10-30 \% \mathrm{wt}$., the reduction in conversion was lower. These authors pointed out that this phenomenon could be explained by the formation of second phase in the reaction medium at the beginning of the reaction, and in this case both alcohol and water are partially eliminated from direct contact with the enzyme, thus increasing the yield (Botton et al., 2018). In our case the reaction medium contained $50 \%$ wt. water, so two phases were probably formed, hence the reduction in yield was only $3 \%$. In this case, a small change in the fatty acid profile was detected (Table 3), mainly towards the increase in saturated fatty acids.

Heterogeneous catalysts. Acid homogeneous catalysts, such as $\mathrm{H}_{2} \mathrm{SO}_{4}$ and $\mathrm{HCl}$, are corrosive liquids. Alternatives to this type of acid catalysts are heterogeneous catalysts, which minimize environmental problems and can reduce biodiesel production costs (Borges and Díaz, 2012), hence the esterification with Amberlyst-15 and biocatalysts from the pyrolyzed roots of $J$. curcas L. was assayed. Several works can be found in the literature dealing with the heterogeneous catalysis of FFA esterification reactions of oils with relative low acidity (5-15\% wt. FFA) to avoid saponification in the subsequent TG transesterification (Kastner et al., 2012; Hidayat et al., 2015). However, there is a lack of papers concerning the FFA esterification of oils with high acidity such as the raw material used in this research. The main objective of this part of the work was to compare the performance of Amberlyst-15 with that of the five biocatalysts, whose main characteristics are shown in Table 4. As expected, the catalyst treated with $\mathrm{CO}_{2}$ (Biocatalyst 3) presented the highest specific surface area. The characteristics of our biochars were similar (in the same order of magnitude) to those of other biocatalysts, mainly sulfonated biochars, and ionexchange resins used for FFA esterification (Örbay et al., 2008; Kastner et al., 2012). In this sense, BET surface area and average pore diameter of coconut shell biochar were reported to be $244.2 \mathrm{~m}^{2} \cdot \mathrm{g}^{-1}$ and $4.86 \mathrm{~nm}$, respectively (Hidayat et al., 2015).

Firstly, we assessed the esterification performance of Amberlyst-15. It was observed that the greater the amount of catalyst, the higher the yield, i.e. AI decreased, as pointed out by other authors (Özbay et al., 2008). These authors concluded that the best esterification conditions were $15 \%$ wt. Amberlyst- 15 at $60{ }^{\circ} \mathrm{C}$. Then, using this optimal amount of catalyst, the influence of the $\mathrm{MeOH}: \mathrm{RO}$ molar ratio was studied. In this case, the higher the molar ratio, the higher the yield. No improvement was observed when increasing the molar ratio from $15: 1$ to $20: 1$, so the former one was selected for trials with biocatalysts. Among the biocatalysts, the one that yielded the most was the pyrolyzed roots activated with $\mathrm{H}_{3} \mathrm{PO}_{4}$ (Biocatalyst 1), which was the one with the highest surface area and the smallest pore size (Table 4), followed by the pyrolyzed roots from phytoremediation of the contaminated soil with the greatest concentration of heavy metals (Biocatalyst 5). One last heterogeneous esterification was assayed with this latter biocatalyst with increased methanol to residual oil molar ratio of 20:1 (Table 5). The esterification performance of Biocatalyst 5 increased, producing a $37.8 \%$ reaction yield, yet a little lower than that achieved over Amberlyst-15 under the same conditions (44.4\%). All in all, although the yields obtained in the esterification over biocatalysts were lower than those obtained over homogeneous catalysts, they were similar than those achieved with Amberlyst-15 commercial catalyst, which accounts for the potential of these biochars to catalyze reactions.

\subsection{Transesterification of remaining triglycerides}

With the aim of obtaining a complete conversion of FFA and TG into FAME, the RO was consecutively subjected to TG hydrolysis, FFA esterification

TABLE 4. Characteristics of the assayed heterogeneous catalysts

\begin{tabular}{llccc}
\hline Catalyst & \multicolumn{1}{c}{ Matrix } & $\begin{array}{c}\text { BET surface area } \\
\left(\mathbf{m}^{2} \cdot \mathbf{g}^{-1}\right)\end{array}$ & $\begin{array}{c}\text { Average pore } \\
\text { diameter }(\mathbf{n m})\end{array}$ & $\begin{array}{c}\text { Total pore } \\
\text { volume }\left(\mathbf{c m}^{\mathbf{3}} \cdot \mathbf{g}^{-1}\right)\end{array}$ \\
\hline Amberlyst-15 & Styrene-divinyl-benzene & $53^{\mathrm{a}}$ & $30.0^{\mathrm{a}}$ & $0.4000^{\mathrm{a}}$ \\
Biocatalyst 1 & Carbon & 673 & 3.0 & 0.2564 \\
Biocatalyst 2 & Carbon & 445 & 5.9 & 0.0539 \\
Biocatalyst 3 & Carbon & 92 & 5.7 & 0.0041 \\
Biocatalyst 4 & Carbon & 348 & 4.4 & 0.0466 \\
Biocatalyst 5 & Carbon & 346 & 4.3 & 0.0446 \\
\hline
\end{tabular}

${ }^{\mathrm{a}}$ Data extracted from product data sheet 
TABLE 5. Resulting acidity index (AI) and reaction yield $(\eta)$ achieved in the esterifications carried out with heterogeneous catalysts

\begin{tabular}{llcccr}
\hline Run & Catalyst & \% wt. & MeOH:RO & AI (\%) & \multicolumn{1}{c}{$\boldsymbol{\eta}_{\mathbf{E}}(\%)$} \\
\hline E5 & Amberlyst-15 & 10 & $2: 1$ & $54.6 \pm 0.5$ & $9.7 \pm 0.2$ \\
E6 & Amberlyst-15 & 10 & $8: 1$ & $43.2 \pm 0.3$ & $28.6 \pm 0.5$ \\
E7 & Amberlyst-15 & 10 & $10: 1$ & $37.3 \pm 0.3$ & $38.4 \pm 0.5$ \\
E8 & Amberlyst-15 & 15 & $10: 1$ & $36.2 \pm 0.4$ & $40.2 \pm 0.3$ \\
E9 & Amberlyst-15 & 15 & $15: 1$ & $33.4 \pm 0.2$ & $44.7 \pm 0.7$ \\
E11 & Amberlyst-15 & 15 & $20: 1$ & $33.6 \pm 0.3$ & $44.4 \pm 0.5$ \\
E12 & Biocatalyst 1 & 15 & $15: 1$ & $37.8 \pm 0.4$ & $37.5 \pm 0.3$ \\
E13 & Biocatalyst 2 & 15 & $15: 1$ & $60.2 \pm 0.5$ & $0.5 \pm 0.2$ \\
E14 & Biocatalyst 3 & 15 & $15: 1$ & $54.6 \pm 0.1$ & $9.8 \pm 0.8$ \\
E15 & Biocatalyst 4 & 15 & $15: 1$ & $49.6 \pm 0.3$ & $18.1 \pm 0.5$ \\
E16 & Biocatalyst 5 & 15 & $15: 1$ & $42.5 \pm 0.2$ & $29.8 \pm 0.7$ \\
E17 & Biocatalyst 5 & 15 & $20: 1$ & $37.7 \pm 0.2$ & $37.8 \pm 0.7$ \\
\hline
\end{tabular}

and transesterification of the remaining TG in the same reactor under the most favourable conditions found for each stage. The conditions for TG hydrolysis and FFA esterification were obtained in this work, while those for TG transesterification were selected based on previous works (Pereda Marín et al., 2003; García-Martín et al., 2018, 2019a). To assess the extent of the reaction, mainly the conversion of TG and DG into FFA, HPSEC was selected as the most suitable technique to monitor the reactions.

The starting RO glyceride content (trimers + dimers $+\mathrm{TG}+\mathrm{DG}$ ) was roughly $38 \%$ based on HPSEC data (Table 1). The hydrolysis of these compounds with lipases decreased the glyceride content to $27 \%$, increasing the FFA concentration from 62.4 to $72.8 \%$ (Table 1). In spite of the fact that trimers and dimers were completely hydrolyzed, the results indicated that the TG hydrolysis was not effective, since a large quantity of TG $(12.6 \%)$ and DG $(14.9 \%)$ remained in the RO without releasing their fatty acids. This result is in contrast with the data obtained in Table 2, in which the AI increased from $60.5 \%$ to $85.4 \%$ for run $\mathrm{H} 1$, and this latter AI value does not match the FFA obtained by HPSEC $(72.8 \%)$. The subsequent FFA esterification led to a FFA+FAME concentration of $74.4 \%$. Based on the AI data from Table 3, AI for run HE1 was $4.2 \%$, which could indicate that the residual oil contained roughly $70 \%$ FAME. Finally, the final transesterification stage (HET1) completely converted the TG (Table 1), but not totally into FFA, since the concentration of DG was significant $(18.8 \%)$. The incomplete glyceride transesterification and the increase in DG concentration could have occurred because of an inhibition by-product, since the reaction medium contained at least $74 \%$ FAME at the beginning of the transesterification, thus displacing the reaction toward the formation of intermediate reaction products such as DG. It could be also due to the remaining FFA from the esterification stage, which form soaps and inhibit the transesterification (García-Martín et al., 2018). The final FAME concentration provided by HPSEC at the end of the 3 -stage scheme was $81.2 \%$ wt., which was in agreement with the value obtained by GC-MS $(84.0 \pm 2.1 \%)$.

\section{CONCLUSIONS}

The most favorable conditions for triglyceride prehydrolysis were $0.081 \%$ wt. lipase, 1:1 water:residual oil ratio $(\mathrm{v} / \mathrm{v}), 24 \mathrm{~h}$ reaction time, $30{ }^{\circ} \mathrm{C}$ temperature and $700 \mathrm{rpm}$ stirring. Homogeneous catalysts showed higher performance than heterogeneous catalysts for fatty acid esterification. The optimal conditions for esterification were $5 \%$ wt. $\mathrm{H}_{2} \mathrm{SO}_{4}$, 15:1 methanol:residual oil molar ratio, $2 \mathrm{~h}$ reaction time, $60^{\circ} \mathrm{C}$ temperature and $700 \mathrm{rpm}$ stirring. While the esterification and transesterification processes did not modify the fatty acid profile, the hydrolysis with lipases seemed to exert some effect on it, mainly toward the decrease in the degree of unsaturation. The proposed three-stage process (hydrolysis, esterification plus transesterification) achieved a high methyl ester yield ( $84 \%$ wt.). The experimental results show that this residual oil with a high acidity index can be regarded as raw material to produce fatty acid methyl esters.

\section{ACKNOWLEDGMENTS}

This work was supported by the European Union Funds under grant LIFE 13-Bioseville ENV/1113. The authors are grateful to Grupo BIOSEL for supplying the residual oil.

\section{REFERENCES}

Álvarez-Mateos P, Alés-Álvarez FJ, García-Martín JF. 2019. Phytoremediation of highly contaminated mining soils by Jatropha curcas L. and production of catalytic carbons from the generated biomass. J. Environ. Manag. 231, 886-895. https://doi.org/10.1016/j.jenvman.2018.10.052

Bastidas M, Buelvas LM, Marquez MI, Rodriguez K. 2010 Producción de carbón activado a partir de precursores carbonosos del Departamento del Cesar, Colombia. Inf. Tecnol. 21, 87-96.

Borges ME, Díaz L. 2012. Recent developments on heterogeneous catalysts for biodiesel production by oil esterification and transesterification reactions: A review. Renew. Sust. Ener. Rev. 16, 2839-2849. https://doi.org/10.1016/j. rser.2012.01.071

Botton V, Piovan L, Meir HF, Mitchell DA, Cordova J, Kriege N. 2018. Optimization of biodiesel synthesis by esterification using a fermented solid produced by Rhizopus microsporus on sugarcane bagasse. Bioprocess Biosyst. Eng. 41, 573-583. https://doi.org/10.1007/s00449-018-1892-5

Chai M, Tu Q, Lu M, Yang YJ. 2014. Esterification pretreatment of free fatty acid in biodiesel production, from laboratory to industry. Fuel Process. Technol. 125, 106-113. https://doi.org/10.1016/j.fuproc.2014.03.025 
Chowdhury A, Sarkar D, Mitra D. 2016. Esterification of Free Fatty Acids Derived from Waste Cooking Oil with Octanol: Process Optimization and Kinetic Modeling. Chem. Eng. Technol. 39, 730-740. https://doi.org/10.1002/ ceat. 201400745

Cvengroš J, Cvengrošová Z. 2004. Used frying oils and fats and their utilization in the production of methyl esters of higher fatty acids. Biomass Bioeng. 27, 173-181. https://doi. org/10.1016/j.biombioe.2003.11.006

García-Martín JF, Barios CC, Alés-Álvarez FJ, DomínguezSáez A, Álvarez-Mateos P. 2018. Biodiesel production from waste cooking oil in an oscillatory flow reactor. Performance as a fuel on a TDI diesel engine. Renew. Ener. 125 546-556. https://doi.org/10.1016/j.renene.2018.03.002

García-Martín JF, Alés-Álvarez FJ, López-Barrera MC, Martín-Domínguez I, Alvarez-Mateos P. 2019. Cetane number prediction of waste cooking oil-derived biodiesel prior to transesterification reaction using near infrared spectroscopy. Fuel 240, 10-15. https://doi.org/10.1016/j. fuel.2018.11.142

García-Martín JF, Alés-Álvarez FJ, Torres-García M, Feng CH, Alvarez-Mateos P. 2019. Production of oxygenated fuel additives from residual glycerine using biocatalysts from heavy-metal-contaminated Jatropha curcas L. roots. Energies 12 (4), 740. https://doi.org/10.3390/en12040740

García Martín JF, López Barrera MC, Torres García M, Zhang QA, Álvarez Mateos P. 2019. Determination of the acidity of waste cooking oils by near infrared spectroscopy. Processes 7 (5), 304. https://doi.org/10.3390/pr7050304

González I, González JA. 2015. Aceites usados de cocina. Problemática ambiental, incidencias en redes de saneamiento y coste del tratamiento en depuradoras. Aguas Resid. Inf. 1-8. Available at: http://www.aguasresiduales. info/revista/articulos/problematica-ambiental-incidenciasen-redes-de-saneamiento-y-coste-del-tratamiento-endepuradoras-de-los-aceites-usados-en-cocina.

Hidayat A, Rochmadi, Wijaya K, Nurdiawati A, Kurniawan W, Hinode H, Yoshikawa K, Budiman A. 2015. Esterification of palm fatty acid distillate with high amount of free fatty acids using coconut shell char based catalyst. Energy Proced. 75, 969-974. https://doi.org/10.1016/j.egypro.2015. 07.301

Kastner JR, Miller J, Geller DP, Locklin J, Keith LH, Johnson T. 2012. Catalytic esterification of fatty acids using solid acid catalysts generated from biochar and activated carbon. Catal. Today 190, 122-132. https://doi.org/10.1016/j. cattod.2012.02.006

Leung DYC, Guo Y. 2006. Transesterification of neat and used frying oil: Optimization for biodiesel production. Fuel Process. Tech. 87, 883-890. https://doi.org/10.1016/j. fuproc.2006.06.003

Marchetti JM, Errazu AF. 2008. Esterification of free fatty acids using sulfuric acid as catalyst in the presence of triglycerides. Biomass Bioen. 32, 892-895. https://doi.org/10.1016/j. biombioe.2008.01.001

Ministerio de Agricultura y Pesca Alimentacion y Medio Ambiente. 2017. Informe del consumo de alimentación en España 2016', p. 242.

Mittelbach M, Enzelsberger H. 1999. Transesterification of heated rapeseed oil for extending diesel fuel. $J$. Am. Oil Chem. Soc. 76, 545-550. https://doi.org/10.1007/ s11746-999-0002-x

Nawar WW. 1984. Chemical Changes in Lipids Produced by Thermal Processing. J. Chem. Educ. 61, 299-302. https:// doi.org/10.1021/ed061p299

Özbay N, Oktar N, Tapan NA. 2008. Esterification of free fatty acids in waste cooking oils (WCO): Role of ion-exchange resins. Fuel 87, 1789-1798. https://doi.org/10.1016/j.fuel. 2007.12.010

Pereda Marín J, Barriga Mateos F, Álvarez Mateos P. 2003. Aprovechamiento de las oleinas residuales procedentes del proceso de refinado de los aceites vegetales comestibles, para la fabricación de biodiesel. Grasas Aceites 54 (2), $130-137$.

Sánchez-Gimeno AC, Benito M, Vercet A, Oria R. 2008. Aceite de oliva virgen extra del Somontano: evaluación de las modificaciones físico-químicas tras la fritura doméstica de patatas prefritas congeladas. Grasas Aceites 59, 57-61. https://doi.org/10.3989/gya.2008.v59. i1.491

Uribe LM, López ME, Gonzáles AG. 2013. Activación de carbón mineral mediante proceso físico en horno tubular horizontal y atmósfera inerte. Rev. Colombiana Material. 4, 93-108.

Vitiello R, Li C, Russo V, Tesser R, Turco R, Di Serio M. 2017. Catalysis for esterification reactions: a key step in the biodiesel production from waste oils. Rend. Fis. Acc. Lincei, 28, 117-123. https://doi.org/10.1007/s12210-016-0570-2 